\title{
OCEANOGRAPHIC VARIABILITY IN THE INNER SHELF OF PARANÁ, BRAZIL: SPRING CONDITION
}

\author{
Mauricio Almeida Noernberg ${ }^{1}$ and André Luiz Alberti²
}

\begin{abstract}
The hydrographic and hydrodynamics data obtained from a 10 meters deep mooring (0.5 meter above the bottom) located in the Inner Shelf of Paraná, Brazil, from Oct/11/2006 to Dec/10/2006, were analyzed. The oceanographic variability was characterized by maximum values of $54.2 \mathrm{~cm} . \mathrm{s}^{-1}$ for current, $2.9 \mathrm{~m}$ for height, and $10 \mathrm{~s}$ for wave period. The salinity ranged from 32 to $33.7 \mathrm{ups}$ and temperature from 20.7 to $25.3^{\circ} \mathrm{C}$. The wind stress is the main force driving the oceanographic variability, especially during high-energy events, generating waves bigger than $2.5 \mathrm{~m}$, which occur with periods of 7.6 days. The low frequency oscillations dominate the behavior of longshore currents. These currents also answer more effectively to the wind variability. The most important tidal components were the lunar and solar semi-diurnal, $\mathrm{M}_{2}$ and $\mathrm{S}_{2}$, respectively. The temperature and salinity response to the wind effect is faster than circulation pattern response. However, the variability of temperature and salinity associated with the wind energy peaks still needs to be better understood. For this, we need a better understanding of the sources of heat and salt, both local and remote, as well as their variability.
\end{abstract}

Keywords: hydrography, currents, waves, winds, cold fronts, Paraná.

RESUMO. Neste trabalho foram analisados dados hidrográficos e hidrodinâmicos obtidos a 0,5 metros acima do fundo através de fundeio a 10 metros de profundidade localizado na Plataforma Continental Interna do Paraná entre 11/out/2006 e 10/dez/2006. A variabilidade oceanográfica foi caracterizada por valores máximos de correntes de $54,2 \mathrm{~cm} \cdot \mathrm{s}^{-1}, 2,9 \mathrm{~m}$ para altura e $10 \mathrm{~s}$ para o período das ondas. A salinidade variou de 32 a 33,7 e a temperatura da água entre 20,7 a $25,3^{\circ} \mathrm{C}$. A tensão do vento é a principal forçante que governa a variabilidade dos parâmetros oceanográficos, especialmente nos eventos de alta energia, gerando ondas maiores que 2,5 m, que ocorrem com períodos de 7,6 dias. As oscilações de baixa frequência dominaram o comportamento das correntes longitudinais. Estas correntes também respondem mais efetivamente à variabilidade do vento. As componentes de maré de maior amplitude foram as componentes lunar e solar semidiurnas $\mathrm{M}_{2} \mathrm{e}$ $\mathrm{S}_{2}$, respectivamente. A resposta da temperatura e da salinidade em função da ação do vento ocorre de forma mais imediata que a resposta do padrão de circulação. Entretanto, a variabilidade da temperatura e salinidade associada aos picos de energia do vento ainda precisa ser mais bem compreendida. Para tal, é necessário um melhor conhecimento das fontes de calor e sal, tanto locais quanto remotas, bem como de suas variabilidades.

Palavras-chave: hidrografia, correntes, ondas, ventos, frentes frias, Paraná.

\footnotetext{
${ }^{1}$ Center for Marine Studies, Universidade Federal do Paraná - CEM/UFPR, Av. Beira Mar s/n, Pontal do Sul, P.0. Box 61, 83255-976 Pontal do Paraná, PR, Brazil. Phone: +55(41) 3511-8614; Fax: +55(41) 3511-8614 - E-mail: m.noernberg@ufpr.br

${ }^{2}$ Graduate Program in Coastal and Ocean Systems - PGSISCO, Universidade Federal do Paraná - UFPR, Av. Beira Mar s/n, Pontal do Sul, P.0. Box 61, 83255-976 Pontal do Paraná, PR, Brazil - E-mail: andreluizalberti@yahoo.com.br
} 


\section{INTRODUCTION}

Flows in shallow environments, such as inner shelf, exhibit more complex patterns than deeper environments such as the outer shelf and oceanic basins. Most often these complex patterns are caused by the wide variability of processes occurring there, such as surface waves, buoyancy governed flows, force of winds, tides, internal waves, boundary layer effects, and interactions with the bottom and coastline.

The inner shelf consists of the continental shelf region where the Ekman surface and bottom (Mitchum \& Clarke, 1986) layers interact. It is in this region that the surface Ekman transport is blocked and also the currents governed by the wind can be as or more intense than in other regions of the continental shelf (Lentz, 1995).

The inner shelf is among the marine regions of great interest because it represents the continent-ocean transition zone, and the region of intense extractive or productive activities. It is also in this region and the coastline where extreme events and natural or anthropogenic accidents usually cause great impact on the physical, biological and social systems.

However, despite their importance, these high-energy coastal environments have received less attention compared to other oceanic areas. Logistical difficulties, such as the inaccessibility of large research vessels and the difficulty of maintaining instruments in areas under the action of waves, fishing and vandalism, in addition to the physical complexity of these margin systems, probably have been restricting oceanographic studies in these sectors.

Understanding the dynamics of the inner shelf, through in situ measurements, is fundamental to understanding, monitoring and managing the coastal resources, also favoring the validation of different models. This paper presents the variability of oceanographic parameters and their forcings from data obtained on a mooring in the inner shelf of the state of Paraná, Brazil, between October and December 2006.

\section{METHODOLOGY}

The study area is located in the Inner Continental Shelf of Paraná (ICSPR), at the southern portion of the Southeast Brazilian Continental Shelf (SBCS). Figure 1 shows the study area, location of the anchorage and the local bathymetry. An InterOcean S4-ADW electromagnetic current meter equipped with wave meter and CTD was installed in the mooring location $\left(25^{\circ} 38.5^{\prime} \mathrm{S}, 48^{\circ} 24.5^{\prime} \mathrm{W}\right)$ approximately $0.5 \mathrm{~m}$ from the seabed for a period of 60 days ( $0 \mathrm{c}-$ tober 11 -December 10, 2006). The instrument measured current speed and direction for 1 minute at 30-minute intervals, together with temperature and conductivity. Wave direction, height and period data were measured over 18 minutes every 3 hours (Table 1).

Unfortunately, currents and directional waves, as well as conductivity data were unreliable from November, 1st due to bioincrustration problems. Therefore, the data will be presented and analyzed separately in two series; Series 1 is the initial period of 21 days (October 11 - December 10, 2006) with directional information of currents and waves, temperature and salinity; and, Series 2 corresponds to the analysis of the complete series (60 days) but using only the data regarding water temperature, current velocity, height and significant periods of waves and sea level height.

The meteorological data (wind speed and direction) were obtained from the weather station of the Center for Marine Studies for the same mooring time period with hourly rate/frequency (Table 2). The hourly data from two weather stations of the Center for Environmental Information and Hydrometeorology of Santa Catarina (EPAGRI/CIRAM), Porto de São Francisco and Ilha do Arvoredo were also used. The wind speed data were converted to units of wind stress $(\tau)$ using the formulas of Smith (1980).

With the exception of wave data, in the analysis of Series 2, the oceanographic mooring data were reduced to the same frequency of meteorological data (hourly) by simply selecting the hourly data (on the top of the hour) for cross-correlation analysis.

In the analysis of Series 1, the magnetic declination of the speed vector data of the currents and wind stress were corrected and decomposed into longitudinal and transverse components to the shore, as described by Miranda et al. (2002). The positive sign of the longshore components indicates movement toward the equator while for the transverse components indicates movement from the coast towards the ocean.

The low-pass Lanczos-cosine filter (Thompson, 1983) with a cutoff frequency of $1 / 40$ hours, which removes $95 \%$ of oscillations with frequencies lower than $1 / 25$ hours, was used to eliminate high frequency signals (wind breeze, tide and inertial period, this corresponds to approximately $28 \mathrm{~h}$ for the study region).

The dominant oscillations in the series of data were determined by spectral analysis of variance that partitions a function of frequency based on Fast Fourier Transform (FFT). This technique allows a detailed characterization of the distribution of the variance of each series in the frequency domain (Emery \& Thomson, 2004). The analyses were based on the method of Welch (1967), using a Hanning type window with $1 / 3$ of the total length of the series, $50 \%$ overlapping, and confidence interval of $95 \%$. This approach is necessary to increase the statistical reliability of the analysis, although there is loss of spectral resolution. 


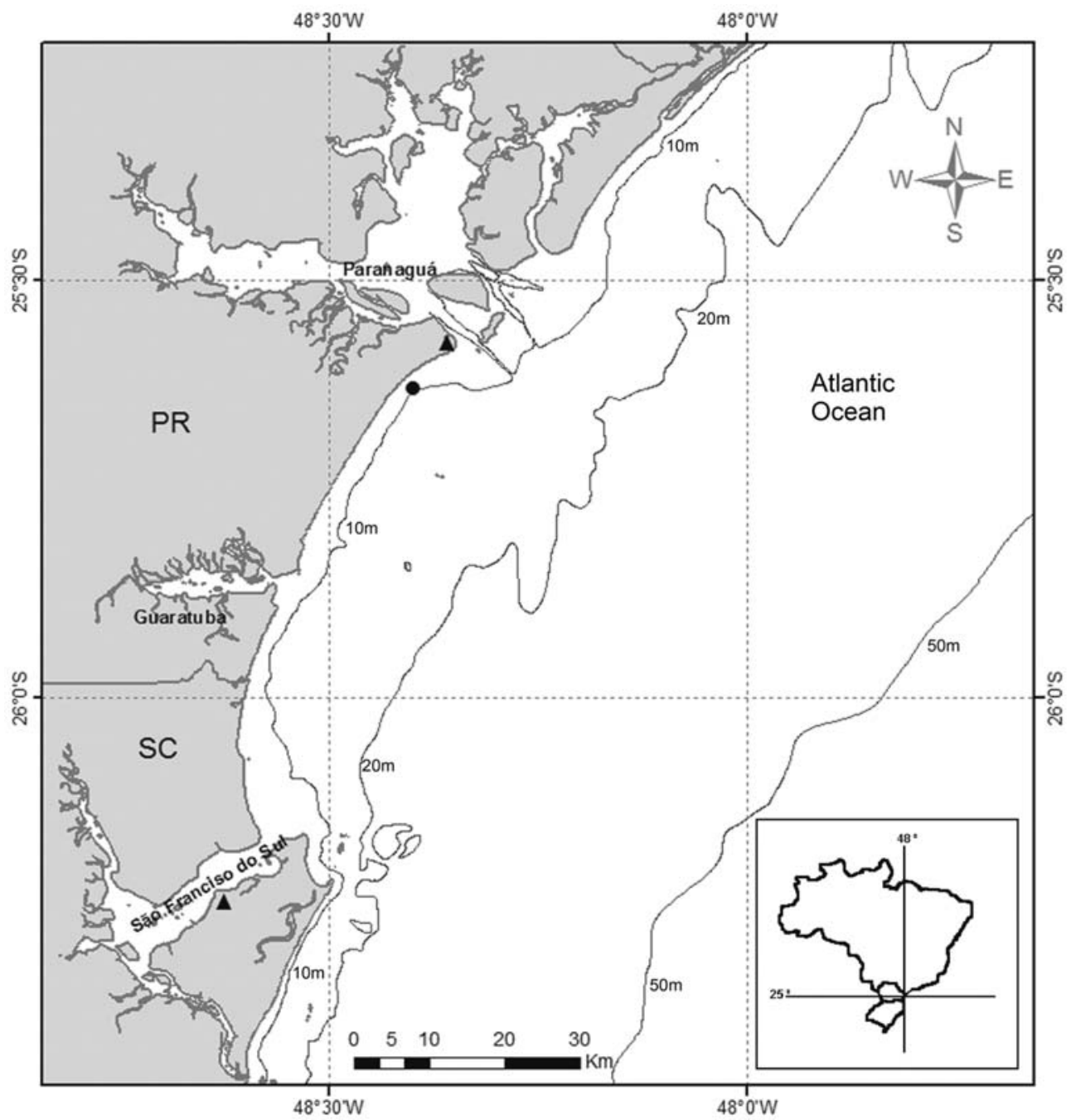

Figure 1 - The study area. The bathymetric contours correspond to isobaths of 10,20 and $50 \mathrm{~m}$. The locations of the meteorological stations in Pontal do Sul and São Francisco do Sul (triangles) in addition to the mooring site (circle) are also shown.

Table 1 - Details regarding oceanographic data.

\begin{tabular}{|c|c|c|c|}
\hline Parameter & $\begin{array}{c}\text { Duration of } \\
\text { the measure }\end{array}$ & $\begin{array}{c}\text { Frequency of } \\
\text { measurement }\end{array}$ & Sampling interval \\
\hline $\begin{array}{c}\text { Current direction and intensity, salinity, } \\
\text { temperature and tide height }\end{array}$ & 1 minute & $2 \mathrm{~Hz}$ & 30 minutes \\
\hline Wave height, period and direction & 18 minutes & $2 \mathrm{~Hz}$ & 120 minutes \\
\hline
\end{tabular}

Table 2 - Details regarding meteorological data.

\begin{tabular}{|c|c|c|c|}
\hline Station & Location & Sampling rate & Sampling interval \\
\hline Pontal do Sul - PR & $\begin{array}{c}25^{\circ} 34.8^{\prime} \mathrm{S} \\
48^{\circ} 21.2^{\prime} \mathrm{W}\end{array}$ & $\begin{array}{c}1 \text { second } \\
(3,600 \text { samples })\end{array}$ & 60 minutes \\
\hline São Francisco do Sul - SC & $\begin{array}{c}26^{\circ} 14.0^{\prime} \mathrm{S} \\
48^{\circ} 42.0^{\prime} \mathrm{W}\end{array}$ & $\begin{array}{c}1 \text { second } \\
(3,600 \text { samples })\end{array}$ & 60 minutes \\
\hline IIha do Arvoredo - SC & $\begin{array}{c}27^{\circ} 17.7^{\prime} \mathrm{S} \\
48^{\circ} 21.4^{\prime} \mathrm{W}\end{array}$ & $\begin{array}{c}1 \text { second } \\
\text { (3,600 samples) }\end{array}$ & 60 minutes \\
\hline
\end{tabular}




\section{RESULTS}

During the 21 days of Series 1, two high energy events with significant wave height larger than $2.5 \mathrm{~m}$ (Fig. 2e) along SSE direction (140-150 $)$ were recorded, which influenced all measured parameters. In longitudinal components of wind stress and currents, the predominant direction is towards the equator, while transverse currents tend to flow toward the ocean, yet fast flux reversals towards the coast occur, associated with energy peaks (Fig. 2d). In terms of average values (Table 3), the direction of the longitudinal component was southward with a value of $-2.1 \mathrm{~cm} . \mathrm{s}^{-1}$ and the transverse component had a mean value of $+9.6 \mathrm{~cm} \cdot \mathrm{s}^{-1}$. However, the maximum value of the longitudinal component was northward; $45.0 \mathrm{~cm} \cdot \mathrm{s}^{-1}$ and for the transverse component; $+25.8 \mathrm{~cm} \cdot \mathrm{s}^{-1}$. The mean longitudinal wind stress was northward with a value of $+0.01 \mathrm{~N}^{-\mathrm{m}^{-2}}$ and a maximum of $+0.23 \mathrm{~N} . \mathrm{m}^{-2}$, while the average and maximum values of the transverse wind stress were $-0.02 \mathrm{~N} . \mathrm{m}^{-2}$ and $-0.17 \mathrm{~N} . \mathrm{m}^{-2}$ respectively.

The air temperature tends to drop and has less variability during these higher energy events (Fig. 2j). Peaks (up to $2^{\circ} \mathrm{C}$ ) in seawater temperature and submareal frequency (Figs. $2 \mathrm{~h}$ and 2i) also occur associated with these events. Salinity variation (Fig. 2g) was 32 and 33.7 psu during the period and showed an inverse relationship with the sea water temperature $(r=-0.57)$. The largest increases in water salinity precede the peaks of energy (wind, currents and waves).

In series 1 the diurnal cycles are well marked, especially the sea breeze (Figs. 2a and 2b) and the tidal currents (Figs. 2c and 2d) signals, and both transverse and longshore coastal components. The low frequency oscillation is responsible for $59.2 \%$ of the total variance of the longitudinal component and $53.0 \%$ of the transverse component of the current, showing a predominance of oscillations in submareal frequencies over tidal frequencies.

In the analysis of series 2 (60 days) current data are presented in scalar form and not as vector. For the reasons described above no salinity data will be presented.

As seen in series 1, the high-energy events associated with frontal systems, with intensifying S-SE winds (Figs. 3a and 3b), promote sea agitation, increase in wave height and sea level, and intensification of the currents (Figs. 3c, 3d, 3e and 3f). Peaks in sea water temperature also occur, associated with these energy peaks (Fig. 3g), which increase progressively as summer approaches. Interestingly, in late November and early December there were two wind stress intensification events that did not cause any response from the waves, currents and temperature, of the same magnitude as the previous ones.
The main components of tide obtained from harmonic analysis are presented in Table 4 . The components of greater amplitude were the semi-diurnal lunar and solar components, $\mathrm{M}_{2}$ and $\mathrm{S}_{2}$, respectively.

\section{DISCUSSION}

The main mechanisms of turbulent mixing in the inner shelf are the friction of the currents with the seabed and the shear stress of the wind during weather events with high winds (Lentz, 1995).

The importance of winds in the dynamics of the Continental Shelf of São Paulo has been well described by Castro \& Lee (1995). On the synoptic weather scale, meteorological disturbances, through mechanisms of ocean-atmosphere interaction, are sources of energy and movement especially in the shallow areas of the coastal zone (Castro, 1990). Among the disorders, the passage of frontal systems is the most relevant in determining the variability of the circulation pattern in SBCS, making the shear strength of the wind one of the most important low frequency mechanisms in the coastal circulation (Stech \& Lorenzzetti, 1992).

The action of the wind in the spring months was remarkable in the oceanographic variability of ICSPR, influencing wave dynamics, currents, sea level, salinity and water temperature. The frontal systems coming from the S and SE quadrants were the most effective in changing oceanographic conditions. The high correlation of wind stress due to the time lag of the wind series of Ilha do Arvoredo (SC), São Francisco do Sul (SC), and Pontal do Sul (PR), shows the action of frontal systems from these quadrants (Fig. 4). The time lag between the Illha do Arvoredo and the São Francisco do Sul and Pontal do Sul stations, was 3 and 4 hours, respectively.

Wind series spectral analysis indicated a peak of 7.6 days, as the most energetic, and another peak of 3.6 days, less energetic, for both components, longitudinal and transverse to the shore. These intervals between consecutive frontal systems are within the range of 3-4 to 12-15 days described as the annual variability of frontal systems in the SBCS, with shorter intervals occurring during spring and winter (Stech \& Lorenzzetti, 1992). Regarding current intensity, the main energetic peaks were 3.6; 5.5; and 24.2 days.

The longitudinal wind component showed higher correlation with current intensity than the transverse component (Fig. 5). The time lag between the longitudinal component of the wind and the current intensity was between 6 and 7 hours. The time lag was the same when only the total wind stress was used as a scalar measure. The transverse component showed a lag of 4 to 5 hours with current intensity, but with lower correlation values. 

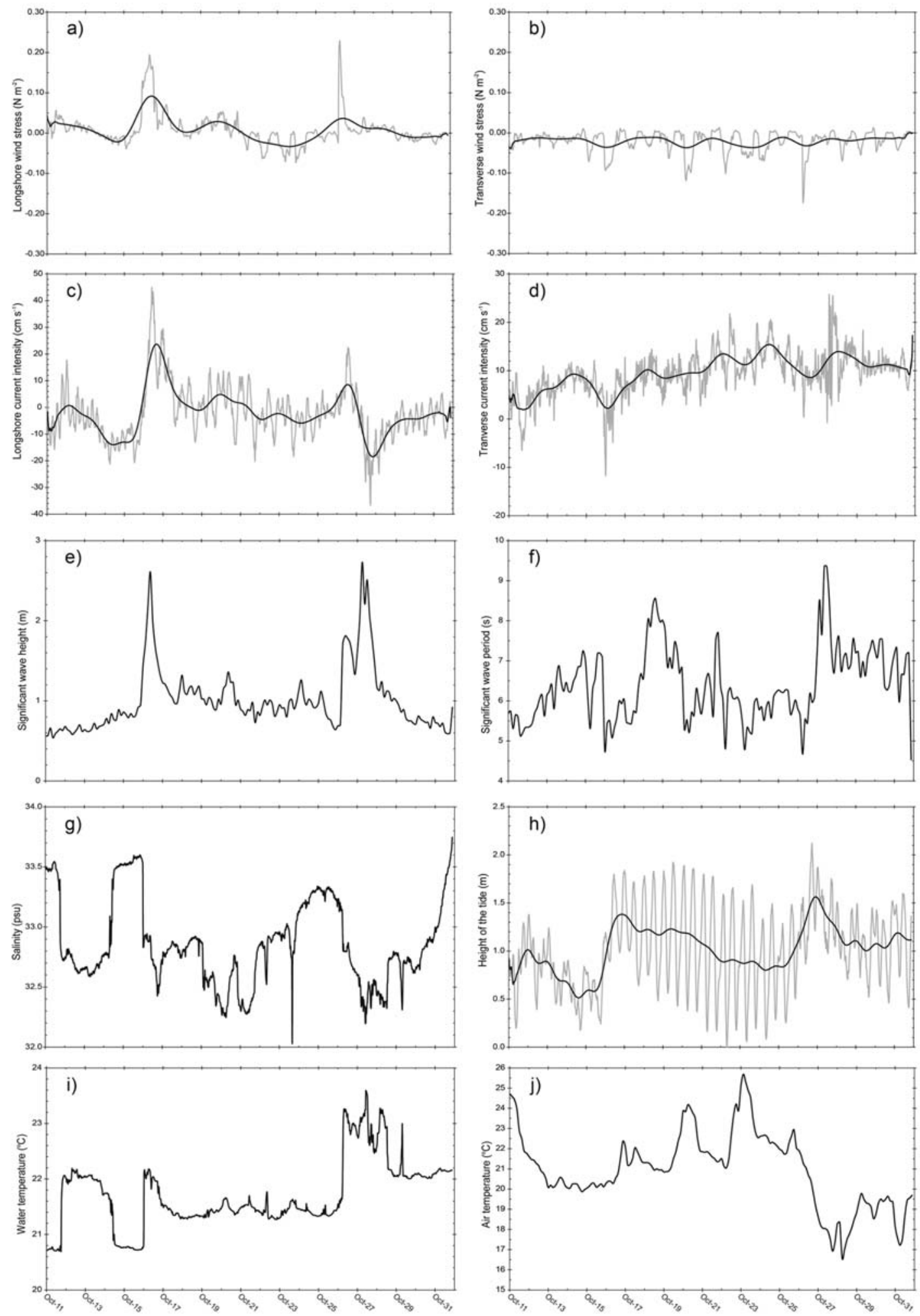

Figure 2 - Series of observed and filtered (in bold) parameters for the period between October 11th and 31st, 2006 a) longitudinal wind stress; b) transverse wind stress; c) longitudinal current; d) transverse current; e) significant wave height; f) significant wave period; g) salinity; h) height of the tide; i) water temperature; and j) air temperature. Hydrological parameters obtained at $0.5 \mathrm{~m}$ above the bottom. For wind and current data, the positive sign of the longitudinal component indicates movement towards the equator, while the positive sign of the transverse component indicates movement from the coast to the ocean. 

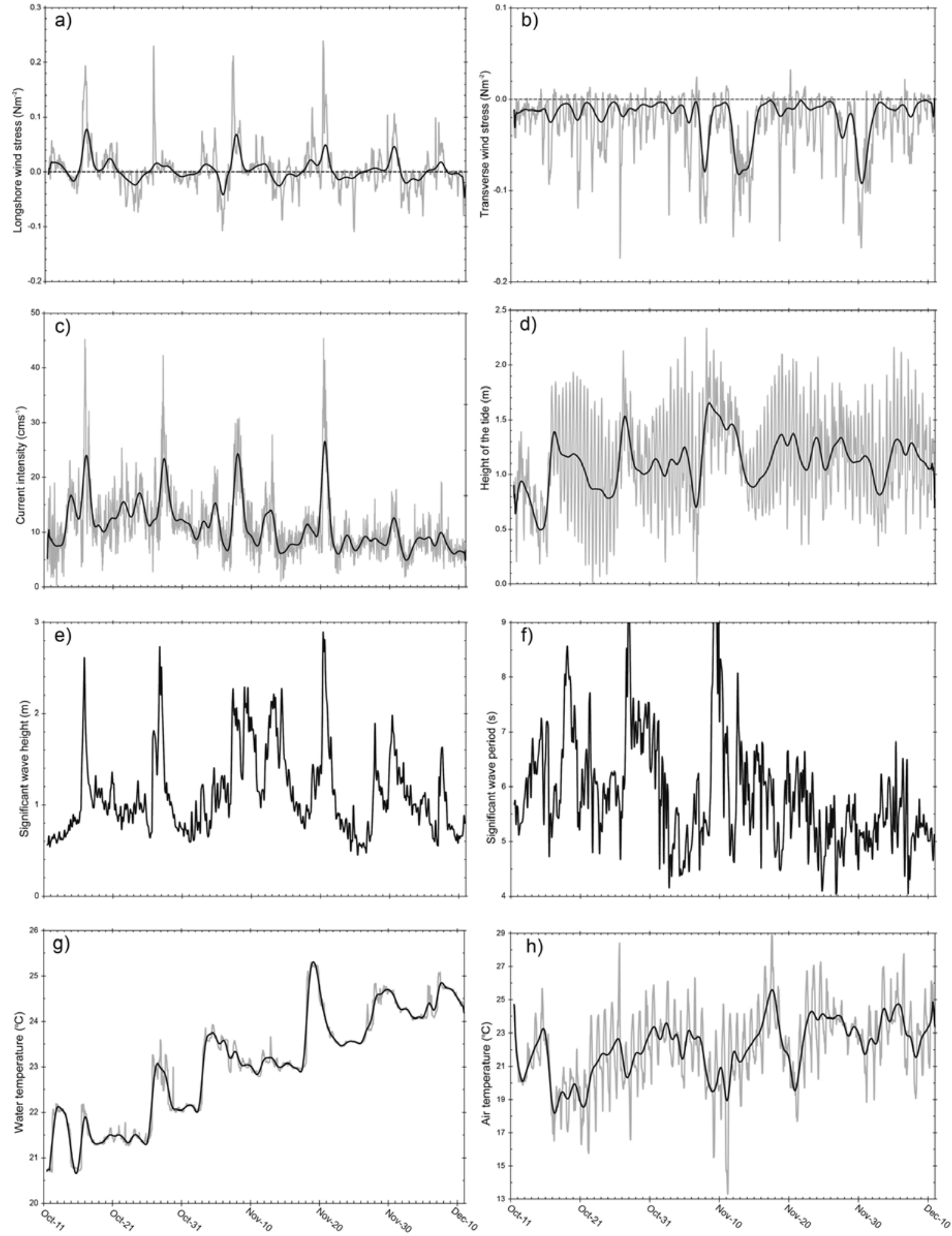

Figure 3 - Series of observed and filtered (in bold) parameters for the period between October 11th and December 10th, 2006 a) longitudinal wind stress; b) transverse wind stress; c) current velocity; d) height of the tide; e) significant wave height; f) significant wave period; g) water temperature; and h) air temperature. Hydrological parameters obtained at $0.5 \mathrm{~m}$ above the bottom. For wind data, the positive sign of the longitudinal component indicates movement towards the equator, while positive sign of the transverse component indicates movement from the coast to the ocean. 
Table 3 - Basic statistics for wind speed and stress, air temperature, current velocity, water temperature, salinity, wave height and period for Series 1 (bold) and Series 2; first 21 days and 60 days, respectively.

\begin{tabular}{|c|c|c|c|c|}
\hline Parameter & Average & $\begin{array}{c}\text { RMS } \\
\text { deviation }\end{array}$ & Minimum & Maximum \\
\hline \multirow{2}{*}{ Wind speed $\left(m \cdot s^{-1}\right)$} & 3.28 & 2.0 & 0.2 & 12.3 \\
\hline & 4.2 & 2.2 & 0.2 & 12.3 \\
\hline \multirow{2}{*}{$\begin{array}{l}\text { Longshore component } \\
\text { of the wind stress }\left(\mathrm{N}^{-\mathrm{m}^{-1}}\right)\end{array}$} & 0.01 & 0.04 & -0.07 & 0.23 \\
\hline & 0.01 & 0.04 & -0.11 & 0.24 \\
\hline \multirow{2}{*}{$\begin{array}{c}\text { Transverse component } \\
\text { of the wind stress }\left(\mathrm{N} \cdot \mathrm{m}^{-1}\right)\end{array}$} & -0.02 & 0.03 & -0.17 & 0.01 \\
\hline & -0.03 & 0.03 & -0.17 & 0.03 \\
\hline \multirow{2}{*}{ Air temperature $\left({ }^{\circ} \mathrm{C}\right)$} & 21.1 & 2.1 & 15.8 & 28.4 \\
\hline & 22.1 & 2.2 & 13.3 & 28.9 \\
\hline \multirow{2}{*}{ Current velocity $\left(\mathrm{cm} . \mathrm{s}^{-1}\right)$} & 13.5 & 5.7 & 0.3 & 45.2 \\
\hline & 11.1 & 5.6 & 0.3 & 45.2 \\
\hline \multirow{2}{*}{$\begin{array}{l}\text { Longshore component } \\
\text { of the current }\left(\mathrm{cm}^{-1} \mathrm{~s}^{-1}\right)\end{array}$} & -2.1 & 10.0 & -36.5 & 45.0 \\
\hline & - & - & - & - \\
\hline \multirow{2}{*}{$\begin{array}{l}\text { Transverse component } \\
\text { of the current }\left(\mathrm{cm}^{-1} \mathrm{~s}^{-1}\right)\end{array}$} & 9.5 & 4.5 & -11.7 & 25.8 \\
\hline & - & - & - & - \\
\hline \multirow{2}{*}{ Water temperature $\left({ }^{\circ} \mathrm{C}\right)$} & 21.7 & 0.6 & 20.7 & 23.6 \\
\hline & 23.1 & 1.2 & 20.7 & 25.3 \\
\hline \multirow{2}{*}{ Salinity (psu) } & 32.9 & 0.4 & 32.0 & 33.7 \\
\hline & - & - & - & - \\
\hline \multirow{2}{*}{ Significant wave height (m) } & 1.0 & 0.4 & 0.5 & 2.7 \\
\hline & 1.1 & 0.5 & 0.5 & 2.9 \\
\hline \multirow{2}{*}{ Significant period (s) } & 6.4 & 4.5 & 1.1 & 9.4 \\
\hline & 5.9 & 4.0 & 1.0 & 10.0 \\
\hline
\end{tabular}

Table 4 - Main components of tide with their amplitudes and phases.

\begin{tabular}{|c|c|c|}
\hline Component & Amplitude $(\mathrm{cm})$ & Phase \\
\hline $\mathrm{M}_{2}$ & 35.0 & 5.4 \\
\hline $\mathrm{S}_{2}$ & 23.2 & 226.8 \\
\hline $\mathrm{O}_{1}$ & 12.9 & 243.3 \\
\hline $\mathrm{M}_{4}$ & 12.4 & 28.5 \\
\hline $\mathrm{M}_{3}$ & 9.5 & 274.7 \\
\hline $\mathrm{MS}_{4}$ & 6.7 & 338.8 \\
\hline $\mathrm{K}_{1}$ & 6.3 & 250.2 \\
\hline
\end{tabular}

Dottori \& Castro (2009), analyzing hydrographic and current data from all seasons and different depths (40,70, 100 and $200 \mathrm{~m})$ from the São Paulo continental shelf, showed that the sub-inertial response of currents to wind forcing is essentially barotropic, indicating that more than $80 \%$ of the current variance of the middle and inner platform is explained by barotropic mode. The higher energy of the currents along the coast, with respect to the transverse currents, would also be a consequence of geostrophy.

In Series 1 the currents longitudinal to the coast were more energetic and better correlated with the high-energy events (frontal systems) than the transverse ones, resulting towards the south $\left(-2.1 \mathrm{~cm} . \mathrm{s}^{-1}\right)$ and towards the ocean $\left(+9.5 \mathrm{~cm} . \mathrm{s}^{-1}\right)$, respectively (Table 3). At the mouth of the Paranaguá Bay, in the access channel, transverse tidal currents are more energetic than the longshore currents. However, during high-energy events the longshore currents are intensified significantly obtaining the ability to carry the bottom sediments (Noernberg et al., 2007).

The variability of hydrological parameters, despite fluctuations in tide frequency, is also primarily dominated by the wind. However, we need to understand the composition and seasonal variability of SBCS water masses as a whole, to better understand the variability of hydrological parameters.

According to Castro et al. (2008) in the Inner SBCS is located between the coast and the Deep Thermal Front, which separates in the bottom layer, the waters of coastal origin from those of oceanic origin, Coastal Water (CW) and South Atlantic Central Water (SACW), respectively. Due to this dynamic feature associated with intrusions of SACW toward the coast, its width varies seasonally, being narrower in the summer (10-30 km) and wider in the winter (40-80 km) (Castro et al., 2008). 


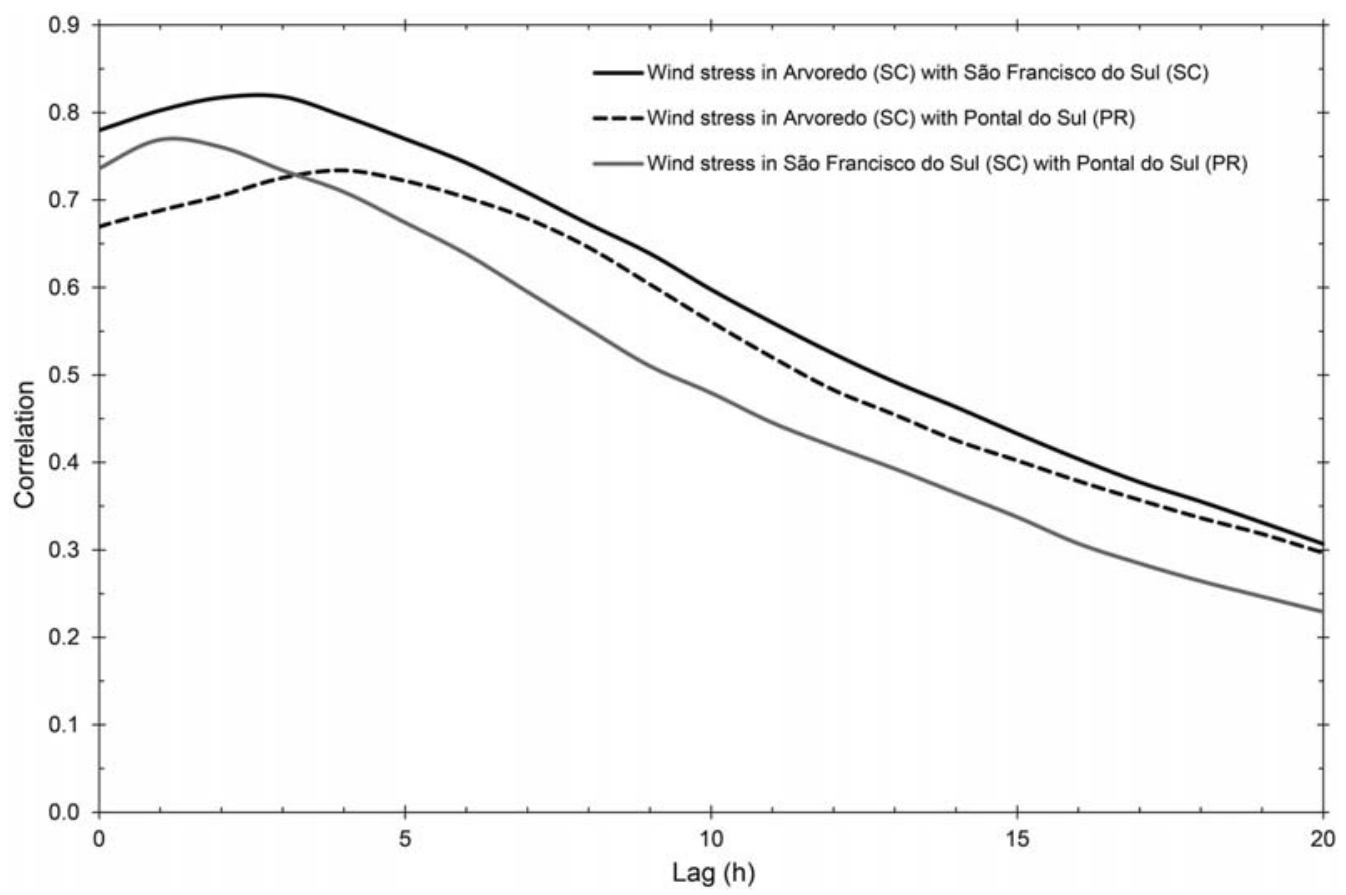

Figure 4 - Correlation between wind stress in llha do Arvoredo (SC), São Francisco do Sul (SC), and Pontal do Sul (PR) as a function of the time lag between the series.

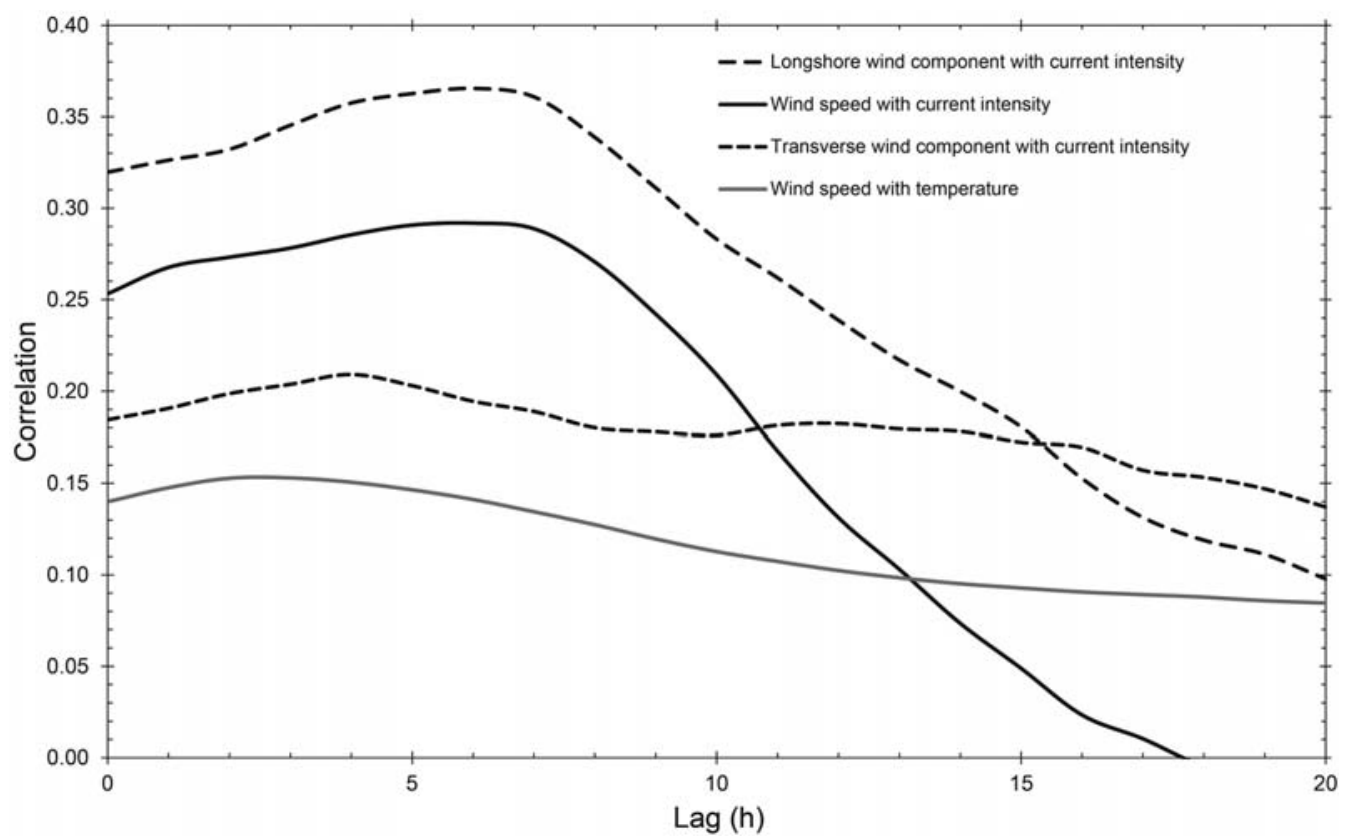

Figure 5 - Correlation between the longitudinal wind stress and current intensity (dashed line); between wind intensity and current intensity (black line); between transverse wind stress and current intensity (dotted), and between wind intensity and water temperature (gray line), as a function of the time lag between the series.

The inner shelf is mainly occupied by CW, which tends to be vertically homogeneous throughout the year, while the middle shelf presents a configuration in two layers; a mixture of waters from the Tropical Water (TW) and the CW form the up- per layer, and SACW the bottom one (Castro \& Miranda, 1998). On the outer platform, the configuration is essentially in two layers, the upper and lower layers filled with TW and SACW, respectively. 
Among the dynamic processes that occur on the SBCS are the orthogonal intrusions of SACW in the summer (Castro \& Miranda, 1998), and the remote fertilization of the continental shelf by the drainage of the La Plata River (Piola et al., 2000). This gradual penetration of water of Subantarctic origin transported north by a coastal branch of the Malvinas Current (MC) is a major oceanographic process that influence the dynamics of the shelf in the coastal and oceanic regions of the south-southeastern Brazil, being mainly observed in the winter months, reaching up to $24^{\circ} \mathrm{S}$ (Silva Jr et al., 1996).

The orthogonal intrusion of SACW can result in coastal upwelling, when it emerges at the surface as a result of the regularity of E-NE winds, especially in spring and summer (Silva et al., 2004). The incidence of S-SE winds favors the subsidence process of surface waters caused by stacking waters off the coast.

The increase in water temperature associated with strong SSE winds in the inner shelf region leads us initially to associate it to a process of coastal subsidence, where the warmer surface waters would flow into deeper layers due to stacking. However, the increase in the water temperature precedes the stacking of water on the shore, characterized by sea level data.

The response of temperature and salinity as a function of the wind activity in ICSPR is more immediate than the response of the current. Taking as an example the high-energy event of October 16th, wind stress peaked at 11:00. Only 90 minutes later the water temperature increased from $20.8^{\circ} \mathrm{C}$ to $22.1^{\circ} \mathrm{C}$ and salinity dropped from 33.5 to $32.8 \mathrm{psu}$. The current began its peak $\left(25.2 \mathrm{~cm} . \mathrm{s}^{-1}\right)$ seven hours after the peak of the wind stress, coinciding with the lag of the whole series (Fig. 5), with its maximum intensity $\left(45.2 \mathrm{~cm} . \mathrm{s}^{-1}\right)$ occurring at 22:00, eleven hours after the maximum wind intensity. The peaks of current intensity coincide with the peaks of significant wave height, which reached $2.2 \mathrm{~m}$ $2.6 \mathrm{~m} \mathrm{18:00}$ and 21:00, respectively. This indicates that the temperature peaks associated with high-energy events in the spring in ICSPR were related to turbulent mixing processes rather than advective processes.

However, it is intriguing that the water temperature rise to values higher than the air temperature (Fig. 2), which leads us to believe that the flow of heat in the ocean-atmosphere interface does not outweigh the advective processes, although no quantitative assessments of heat flow between the ocean and the atmosphere were performed in this study. Probably a combination of advection and turbulent mixing processes acts at different scales of time and space.

The oceanographic conditions in the SBCS in the spring months are characterized by the presence of cold, low salin- ity waters of Subantarctic origin that divide the dynamics of the region with warm, salty waters of tropical origin, transported by the Brazil Current $(\mathrm{BC})$. With the arrival of summer the influence of these subantarctic waters is disappearing in the region, the hot waters influence prevailing. This temperature difference between the cold waters, predominant on the continental shelf, and the warm tropical waters on the slope, results in a strong thermal contrast in this region (Silva Jr et al., 1996).

It is believed that these thermal contrast conditions in the shelf area, together with trapping processes of water due to the coast configuration and the influence of the less saline water discharge of Paranaguá bay, act in this complex mixing mechanism of the inner shelf.

\section{CONCLUSION}

The oceanographic variability of the inner continental shelf of Paraná in the spring period is characterized as a summation of highly variable flows correlated with the local wind stress, dominated by high-energy events with frequency 7.6 days.

The behavior of currents longitudinal to the coast was dominated by low frequency rather than tidal frequencies oscillations. There was a predominance of currents toward the coast and higher correlation of the longshore component of the currents with the wind stress, with predominant flows northward but with inversions southward.

The high-energy weather events, with S-SE winds, caused a significant increase in water temperature, current velocity and wave height. However, the response of the temperature rise to the winds is five times faster than the response of currents and waves.

The mechanisms associated with the occupation of the inner shelf by warmer waters of offshore regions substituting colder southern waters during the spring need to be better understood, together with the sources of variability of hydrological parameters and the mixing mechanisms in the other seasons.

\section{ACKNOWLEDGMENTS}

This work was funded by CNPq: hydrographic characteristics of the Shallow Shelf of Paraná (Universal 2007 CNPq - 480428/ 2007-7). MAN is sponsored by CNPq 308432/2010-0. The authors also gratefully acknowledge the valuable contributions of the anonymous reviewers.

\section{REFERENCES}

CASTRO BM. 1990. Wind driven currents: Channel of São Sebastião: winter, 1979. Boletim do Instituto de 0ceanografia, 38(2): 111-132. 
CASTRO BM \& LEE T. 1995. Wind forced sea level variability on the southeast Brazilian shelf. J. Geophys. Res., 100(C8): 16045-16056.

CASTRO BM \& MIRANDA LB. 1998. Physical Oceanography of the western Atlantic continental shelf located between $4^{\circ} \mathrm{N}$ and $34^{\circ} \mathrm{S}-$ Coastal segment (4,W). In: ROBINSON AR \& BRINK KH (Eds.). The Sea v. 11, John Wiley \& Sons, Inc., p. 209-251.

CASTRO BM, MIRANDA LB, SILVA LS, FONTES RFC, PEREIRA AF \& COELHO AL. 2008. Processos físicos: hidrografia, circulação e transporte. In: PIRES-VANIN MAS (Org.). Oceanografia de um ecossistema subtropical: plataforma de São Sebastião, SP. São Paulo, Editora da Universidade de São Paulo - EDUSP, p. 59-122.

DOTTORI M \& CASTRO BM. 2009. The response of the São Paulo Continental Shelf, Brazil, to synoptic winds. Ocean Dynamics, 59: 603-614.

EMERY WJ \& THOMSON RE. 2004. Data Analysis Methods in Physical Oceanography. Pergamon Press, London, 2nd rev. ed., 634 pp.

LENTZ SJ. 1995. Sensitivity of the inner-shelf circulation to the form of the eddy viscosity profile. J. Phys. Oceanog., 25: 19-28.

MIRANDA LB, CASTRO BM \& KJERFVE B. 2002. Princípios de Oceanografia Física de Estuários. São Paulo, Editora da Universidade de São Paulo - EDUSP, 424 pp.

MITCHUM GT \& CLARKE AJ. 1986. The frictional nearshore response to forcing by synoptic scale winds. J. Phys. Oceanog., 16: 934-946.
NOERNBERG MA, MARONE E \& ANGULO RJ. 2007. Coastal currents and sediment transport in Paranaguá estuary complex navigation channel. Boletim Paranaense de Geociências, 60-61: 45-54.

PIOLA AR, CAMPOS EJD, MÖLLER 00, CHARO M \& MARTINEZ C. 2000. The subtropical shelf front off eastern South America. J. Geophys. Res., 105(C3): 6565-6578.

SILVAJR CL, KAMPEL M, ARAUJO CES \& STECH JL. 1996. Observação da penetração do ramo costeiro da Corrente das Malvinas na costa sulsudeste do Brasil a partir de imagens AVHRR. In: Simpósio Brasileiro de Sensoriamento Remoto, 8., 1996, Salvador. Proceedings... Salvador: INPE, CD-ROM: 787-793.

SILVA LS, MIRANDA LB \& CASTRO BM. 2004. Estudo numérico da circulação e da estrutura termohalina na região adjacente à Ilha de São Sebastião. Brazilian Journal of Geophysics, 22(3): 197-221.

SMITH SD. 1980. Wind stress and heat flux over the ocean in gale force winds. J. Phys. Oceanog., 10: 709-726.

STECH JL \& LORENZZETTI JA. 1992. The response of the South Brazi Bight to the Passage of Wintertime Cold Fronts. J. Geophys. Res., 97(C6): 9507-9520.

THOMPSON R. 1983. Low-Pass Filters to Suppress Inertial and Tidal Frequencies. J. Phys. Oceanog., 13: 1077-1083.

\section{NOTES ABOUT THE AUTHORS}

Mauricio Almeida Noernberg. Oceanographer from FURG (1988), Masters in Remote Sensing at INPE (1996) and PhD in Environmental Geology from UFPR (2001). Associate Professor at the Centro de Estudos do Mar - UFPR. Coordinates the Laboratório de Oceanografia Costeira e Geoprocessamento (CEM-UFPR) and the main research interests are related to hydrodynamics and biophysical processes in coastal and estuarine waters, and the use of remote sensing in coastal environment.

André Luiz Alberti. Oceanographer from UFPR (2005), Master in Coastal and Ocean Systems at UFPR (2010). Substitute professor in Physical Oceanography at UFPR (2011). Currently, is an analyst for energy research and the environment at Empresa de Pesquisa Energética (EPE). Works directly with the Superintendency of Environment, developing the following activities: analysis of the socioeconomic aspects of medium and long term planning in petroleum studies; monitoring and analysis for studies of environmental assessment of sedimentary areas; of environmental impact of energy uses; and other related activities. 